\title{
Perbedaan tingkat keberhasilan 3 metode ekualisasi pada penyelam terlatih di lingkungan air tawar
}

\author{
Bonifacius Arbanto ${ }^{1}$, Kukuh Pambuka Putra ${ }^{2 *}$, Muchamad Arif Al Ardha ${ }^{3}$ \\ ${ }^{1}$ Scuba Schools International, Indonesia Headquarter. Jalan Sekarwaru No.1 Sanur Bali, Indonesia \\ ${ }^{2}$ Faculty of Medicine and Health Science, Universitas Kristen Satya Wacana. \\ Jalan Kartini 11A Salatiga, Jawa Tengah 50711 Indonesia \\ ${ }^{3}$ Department of Curriculum Design and Human Potential Development, National Dong Hwa \\ University. 974, Hualien County, 志學村大學路二 號, Taiwan \\ * Corresponding Author. Email: kukuh.pambuka@outlook.com
}

Received: 12 October 2018; Revised: 6 November 2018; Accepted: 22 December 2018

\begin{abstract}
Abstrak
Penyelam mengalami penambahan tekanan lingkungan ketika bergerak turun menambah kedalaman penyelaman. Tekanan tersebut menyebabkan volume ruang udara dalam telinga tengah berkurang dan dapat menyebabkan barotrauma dan kerusakan membran timpani. Tekanan tersebut harus diseimbangkan dengan cara melakukan ekualisasi. Ada tiga metode ekualisasi, yaitu metode Valsava, Toynbee dan menggerakkan rahang. Namun belum diketahui metode mana yang memiliki tingkat keberhasilan tertinggi. Penelitian ini mempelajari tingkat keberhasilan ketiga metode ekualisasi dengan membandingkan kedalaman yang berhasil dicapai oleh penyelam menggunakan tiga metode yang berbeda. Penelitian ini dilakukan pada 40 orang penyelam terlatih di lingkungan kolam air tawar dengan kedalaman 5 meter. Variabel yang diukur adalah angka kedalaman (dalam meter) yang berhasil dicapai penyelam. Hasil penelitian menunjukkan terdapat perbedaan yang signifikan antara capaian kedalaman menggunakan metode Valsava dengan capaian kedalaman menggunakan metode Toynbee $(\mathrm{p}<0,05)$ dan terdapat perbedaan yang signifikan pula antara capaian kedalaman menggunakan metode Valsava dengan capaian kedalaman menggunakan metode menggerakkan rahang $(p<0,05)$. Namun tidak didapati adanya perbedaan yang signifikan antara data capaian kedalaman menggunakan metode menggerakkan rahang dengan capaian kedalaman menggunakan metode Toynbee $(p>0,05)$.
\end{abstract}

Kata Kunci: ekualisasi, hiperbarik, SCUBA, selam

\section{Difference in success rate of 3 equalize method among trained divers in the freshwater environment}

\begin{abstract}
Divers experience increase of environmental pressure when the diver descends. This pressure causes the volume of air space in the middle ear to decrease, can cause barotrauma and tympanic damage. This pressure must be equalize. There are three methods of equalization, Valsava maneuver, Toynbee and moving the jaw. But it is not known which method has the highest success rate. This research studied the success rate of the three methods of equalization by comparing the depth achieved by divers using the three different methods. This study was conducted on 40 trained divers in the freshwater pool with 5 meters depth. The variable measured is the number of depths (in meters) successfully achieved by divers. The results of this study showed that there was a significant difference between the depth achieved using the Valsava maneuver with the depth achieved using the Toynbee maneuver $(p<0.05)$ and there were also significant differences between the depth achieved using the Valsava maneuver with depth achieved using the jaw moving method $(p<0,05)$. However, there was no significant difference between the depth achieved using the jaw moving method with depth achieved using the Toynbee maneuver ( $p>0.05$ ).
\end{abstract}

Keywords: equalizing, hyperbaric, SCUBA, diving

How to Cite: Arbanto, B., Putra, K., \& Al Ardha, M. (2018). Perbedaan tingkat keberhasilan 3 metode ekualisasi pada penyelam terlatih di lingkungan air tawar. Jurnal Keolahragaan, 6(2), 193-199. doi:https://doi.org/10.21831/jk.v6i2.21560

d

https://doi.org/10.21831/jk.v6i2.21560 
Jurnal Keolahragaan 6 (2), 2018 - 194

Bonifacius Arbanto, Kukuh Pambuka Putra, Muchamad Arif Al Ardha

\section{PENDAHULUAN}

Menyelam adalah suatu aktivitas fisik manusia yang dilakukan di dalam air (Dwipayana, Kusumawati, \& Prapti, 2017; Rithaudin, 2010). Saat ini kegiatan menyelam telah banyak dilakukan oleh masyarakat umum, bahkan selam telah menjadi suatu cabang olahraga dan model rekreasi tersendiri. Dapat ditemui beberapa organisasi yang khusus bergerak di bidang penyelaman. Organisasi-organisasi tersebut biasanya juga menyelenggarakan pelatihan dan memberikan sertifikasi selam secara berjenjang. Jenjang paling dasar yang perlu dikuasai untuk menjadi seorang penyelam adalah pelatihan dasar penyelaman perairan terbuka (Open Water Diving) (Hart, White, Conboy, Bodiwala, \& Quinton, 1999). Dengan memiliki lisensi penyelam perairan terbuka, seseorang dinyatakan memiliki pengetahuan dan keterampilan yang cukup untuk dapat secara legal melakukan aktivitas penyelaman di laut.

Ada dua hukum fisika yang wajib dipahami oleh seorang penyelam, yaitu hukum Boyle dan hukum Henry. Kedua hukum ini wajib dipahami guna mencegah atau mengantisipasi gangguan fisiologis yang dapat terjadi karena efek mekanika tekanan pada ruang udara tertutup (Barotrauma) dan masalah fisiologis yang disebabkan oleh udara dengan tekanan parsial yang tinggi pada tubuh manusia. Hukum Boyle menjelaskan bahwa penyelaman berhubungan dengan tekanan, yang menyatakan bahwa pada suhu konstan, volume gas berbanding terbalik dengan tekanan yang diterapkan. Artinya semakin tinggi tekanan maka volume udara akan semakin berkurang, hal tersebut berhubungan dengan masalah Barotrauma. Sedangkan hukum Henry menjelaskan bahwa jumlah gas yang larut dalam suatu cairan pada suhu tertentu berbanding lurus dengan tekanan parsial gas tersebut. Hal tersebut berarti semakin tinggi tekanan maka jumlah gas terlarut juga semakin besar. Hukum Henry berhubungan dengan penyakit dekompresi pada penyelam (Glazer \& Telian, 2016).

Ketika melakukan aktivitas menyelam, tubuh manusia akan masuk ke lingkungan bawah air yang memiliki tekanan lebih tinggi daripada tekanan udara di permukaan. Tekanan tersebut akan terus meningkat seiring bertambahnya kedalaman penyelaman. Tekanan barometrik pada permukaan laut adalah $1 \mathrm{~atm}(760 \mathrm{~mm} \mathrm{Hg}$ atau 14,7 psi atau $100 \mathrm{kPa}$ ) dan bertambah secara konstan sebanyak $1 \mathrm{~atm}$ setiap 10 meter $(33 \mathrm{ft})$ kedalaman air laut (Brylske, 2006; Davenport,
1979; Glazer \& Telian, 2016; McArdle, Katch, \& Katch, 2009).

Barotrauma merupakan masalah medis yang paling sering ditemui dalam aktivitas penyelaman (Bofe, Martinus, Natsir, \& Tawil, 2018; Ruslam, Rumampuk, \& Danes, 2015). Struktur anatomis tubuh manusia menyebabkan konsekuensi adanya udara yang terperangkap dalam ruang tertutup pada sistem fisiologi tubuh manusia ketika menyelam. Udara yang terperangkap dalam ruang tertutup pada tubuh manusia misalnya pada saluran pernafasan, tulang dan darah. Jika penyelam tidak menyeimbangkan tekanan udara yang terperangkap tersebut ketika proses turun (menambah kedalaman penyelaman) maka volume ruang udara tersebut akan berkurang sesuai hukum Boyle (Davenport, 1979). Namun, volume ruang udara yang terletak pada tulang tidak dapat berkurang karena struktur tulang yang keras, sehingga penyusutan volume akan terjadi pada area lain yaitu membran mukosa. Dalam beberapa kasus peristiwa ini dapat disertai dengan pendarahan (Glazer \& Telian, 2016; Lacey \& Amedee, 2000). Risiko barotrauma lebih besar di dekat permukaan air, di mana sedikit perubahan kedalaman dapat menyebabkan perubahan besar pada volume udara relatif dalam tubuh. Barotrauma dapat terjadi pada struktur mana pun dalam tubuh di mana terdapat ruang tertutup yang dapat di tempati oleh udara termasuk ruang telinga tengah, sinus paranasal, paru, lambung dan usus (Neblett, 2000).

Barotrauma telinga tengah merupakan gangguan medis yang paling sering dialami penyelam pada titik yang sama, yaitu pada saat bergerak turun menambah kedalaman penyelaman (Green, Rothrock, \& Green, 1993; Neblett, 2000). Pada telinga manusia terdapat membran timpani atau gendang telinga (Guyton \& Hall, 2006; Sherwood, 2015) yang ketika menyelam akan terjadi kontak langsung dengan air. Kontak langsung dengan air menimbulkan konsekuensi secara fisik. Ketika penyelam bergerak turun menambah kedalaman penyelaman, tekanan hidrostatik air akan mendorong membran timpani ke arah dalam yang menyebabkan volume udara yang terperangkap di ruang telinga tengah menjadi berkurang. Selain itu tekanan air yang besar dapat merusak membran timpani jika melebihi ketahanan fisik membran timpani karena membran timpani berbentuk selaput tipis. Tidak jarang tekanan tersebut menimbulkan rasa nyeri pada telinga (otalgia). Oleh karena itu diperlukan upaya penyeimbangan dengan menyalurkan 
udara dari saluran pernafasan melalui saluran eustachius, hal ini disebut dengan aktivitas Ekualisasi (equalizing).

Barotrauma telinga tengah terjadi ketika saluran eustachius tidak dapat terbuka untuk menyeimbangkan tekanan udara (Abshor, 2014). Seorang penyelam akan mulai merasakan otalgia ketika terdapat perbedaan tekanan $60 \mathrm{mmHg}$ antara ruang telinga tengah dengan tekanan lingkungan luar. Ketika tekanan telah mencapai 90 $\mathrm{mmHg}$ antara ruang telinga tengah dengan nasofaring, saluran eustachius tidak dapat terbuka meskipun telah diupayakan melakukan ekualisasi (Bove \& Davis, 1990). Jika hal itu terjadi, maka penyelam perlu sedikit mengurangi kedalaman dengan bergerak naik untuk mengurangi tekanan air. Setelah tekanan berkurang maka penyelam dapat melakukan ekualisasi sebelum kembali turun menambah kedalaman (Glazer \& Telian, 2016).

Prinsip utama ekualisasi adalah menyeimbangkan tekanan air lingkungan luar tubuh yang mendorong membran timpani dengan mengalirkan udara yang ada dalam saluran pernafasan ke arah membran timpani melalui saluran eustachius hingga tekanan menjadi seimbang. Pada individu sehat, saluran eustachius dalam kondisi cukup bersih (tidak ada hambatan) sehingga tekanan eksternal yang datang mendorong membran timpani dapat segera. Saat ini diketahui ada 4 cara menyeimbangkan tekanan di rongga telinga tengah tersebut: (1) dengan menggerakkan rahang ke kiri dan ke kanan, (2) meniup perlahan dengan lubang hidung tertutup (teknik Valsava) (3) menelan ludah (metode Toynbee) dan (4) menguap (McArdle et al., 2009).

Keempat metode ekualisasi tersebut memiliki kelebihan dan kelemahan. Tidak jarang penyelam gagal melakukan ekualisasi menggunakan suatu metode tertentu. Metode menggerakkan rahang diakui cukup sulit dilakukan. Selain karena mulut penyelam sedang menggigit mouthpiece yang terhubung dengan selang regulator, udara yang dialirkan ke ruang telinga tengah tidak cukup untuk menyeimbangkan tekanan ruang telinga tengah dengan lingkungan, sehingga pada sebagian orang metode menggerakkan rahang mungkin tidak terlalu memberikan kontribusi yang berarti.

Metode menelan ludah (Toynbee) dalam aplikasinya dapat mengalirkan sejumlah udara ke ruang telinga tengah. Dalam mekanika gerak peristaltik terdapat masa di mana saluran kerongkongan menyempit sesaat sehingga memberikan dorongan terhadap udara yang terjebak di dalam saluran kerongkongan yang terhubung dengan saluran nafas, memberi dorongan yang menyebabkan udara tersebut terdorong melewati saluran eustachius dan masuk ke telinga tengah. Namun karena hanya terjadi sesaat dan gerak peristaltik tidak dapat dikendalikan, terkadang metode ini perlu dilakukan berulang-ulang untuk dapat berhasil menyeimbangkan tekanan. Menelan ludah secara berulang-ulang cukup sulit dilakukan di dalam air terlebih jika dilakukan sambil menggigit mouthpiece dan tidak jarang membuat mulut penyelam menjadi kering.

Metode yang dapat mengalirkan udara dalam jumlah lebih besar adalah metode Valsava yaitu dengan meniup secara lembut melalui hidung dalam kondisi lubang hidung dihambat atau ditutup. Tertutupnya lubang hidung membuat udara mengalir dan memberi tekanan pada area lain (ke segala arah) dalam saluran pernafasan, salah satunya melewati saluran eustachius hingga memasuki ruang telinga tengah. Metode Valsava dinilai lebih mudah dilakukan dan dikendalikan meskipun sambil menggigit mouthpiece. Desain masker saat ini juga telah mendukung metode ekualisasi Valsava. Dengan adanya tonjolan khusus yang memberikan ruang di bagian hidung dengan bahan karet elastis, memungkinkan penyelam menutup hidungnya dengan cara menjepit dengan jari, sehingga metode Valsava lebih mudah dilakukan kapan pun penyelam membutuhkan ekualisasi.

Metode terakhir adalah menguap. Menguap diketahui juga dapat membantu menyeimbangkan tekanan di dalam saluran telinga dengan tekanan lingkungan. Ketika menguap saluran eustachius terbuka karena adanya kontraksi dan relaksasi otot tensor timpani dan otot stapedius (Gupta \& Mittal, 2013), Namun ketika menguap biasanya penyelam akan membuka mulutnya melebihi ukuran mouthpiece dan memungkinkan air masuk ke dalam rongga mulut dalam jumlah besar sehingga akan mengganggu aktivitas pernafasan penyelam. Meskipun penyelam dapat mengatasi hal tersebut namun upaya mengeluarkan air dari dalam rongga mulut akan membuang sejumlah besar udara dari dalam tabung yang seharusnya dioptimalkan untuk bernafas. Oleh karena itu metode menguap tidak dianjurkan dilakukan di dalam air, dan dalam penelitian ini metode menguap akan diabaikan.

Perbedaan mekanisme dari ketiga metode ekualisasi yang mungkin dilakukan di dalam air tersebut menyebabkan tingkat keberhasilan penggunaan metode tersebut juga mungkin akan berbeda. Sampai saat ini belum ada studi yang 
mempelajari tentang perbedaan tingkat keberhasilan penggunaan masing-masing metode ekualisasi tersebut. Penelitian ini bertujuan untuk membandingkan hasil dari penggunaan masingmasing metode ekualisasi pada individu yang sama di lingkungan air tawar. Hasil dari penelitian ini dapat digunakan sebagai acuan bagi penyelam terutama penyelam pemula dan instruktur selam dalam mempertimbangkan pemilihan dan penggunaan metode ekualisasi ketika menjalani pelatihan selam terutama pada tingkat dasar.

\section{METODE}

Penelitian ini merupakan studi analitik observasional (Sastroasmoro \& Ismael, 2011) yang mempelajari perbedaan tingkat keberhasilan ekualisasi ditinjau dari kedalaman yang mampu dicapai oleh penyelam menggunakan tiga metode ekualisasi yang berbeda. Variabel kedalaman penyelaman digunakan dengan asumsi bahwa jika seorang penyelam mampu mencapai suatu kedalaman tertentu maka penyelam tersebut berhasil melakukan ekualisasi ketika perubahan tekanan terjadi. Kegagalan melakukan ekualisasi tidak akan memungkinkan seorang penyelam untuk turun ke kedalaman yang lebih dalam dan akan menimbulkan rasa sakit pada telinga (otalgia) sehingga penyelam secara alami akan cenderung bertahan di kedalaman tersebut dan kedalaman penyelaman tidak akan bertambah.

Observasi dilakukan pada 40 orang penyelam terlatih dan pengukuran dilakukan di kolam air tawar sedalam 5 meter. Subjek diminta untuk menyelam vertikal menggunakan SCUBA dan melakukan hanya satu metode ekualisasi (menggerakkan rahang, metode Valsava atau metode Toynbee) setiap kali menyelam (setiap log). Satu metode ekualisasi dicobakan sebanyak tiga kali (3 log) setiap subjek dan dicatat kedalaman maksimal yang berhasil dicapai dengan menggunakan metode ekualisasi tersebut. Tiga metode ekualisasi tersebut tidak dilakukan dengan urutan tertentu, subjek dapat memilih metode ekualisasi mana yang dilakukan lebih dahulu namun harus diselesaikan sebanyak 3 log sebelum beralih menggunakan metode ekualisasi lainnya. Jumlah total penyelaman (log) yang dilakukan oleh setiap subjek adalah 9 log dengan melakukan 3 metode ekualisasi yang setiap metodenya dicobakan sebanyak 3x. Setelah subjek mencapai kedalaman tertentu dan tidak berhasil melakukan ekualisasi maka subjek akan diminta untuk kembali ke permukaan secara perlahan dengan kecepatan aman 9 meter per menit. Kecepatan tersebut dimaksudkan untuk mencegah pembentukan gelembung udara dalam darah karena perubahan tekanan secara mendadak (McArdle et al., 2009). Durasi dan kedalaman penyelaman dalam penelitian ini aman karena dilakukan di kolam dengan kedalaman maksimal 5 meter dan berada di bawah ambang batas risiko dekompresi sehingga tidak memerlukan safety stop (Hall, 2014).

Seluruh subjek didampingi oleh instruktur dengan lisensi dive professional (instructor) selama penyelaman untuk menjamin keamanan dan keselamatan subjek. Kriteria inklusi yang diterapkan dalam penelitian ini adalah: (1) penyelam terlatih, memahami penggunaan SCUBA dan menguasai metode ekualisasi dengan baik, (2) tidak sedang sakit, (3) tidak mengonsumsi obatobatan atau bahan yang dapat mempengaruhi saluran pernafasan dan pembuluh darah dalam kurun waktu 2 x 24 jam terakhir, (4) bersedia menjadi subjek penelitian dibuktikan dengan mengisi informed consent. Kriteria eksklusi dalam penelitian ini adalah hal-hal lain di luar kriteria inklusi. Data yang diperoleh kemudian dilakukan uji statistik untuk melihat adanya perbedaan bermakna antar capaian kedalaman dari ketiga metode ekualisasi.

\section{HASIL DAN PEMBAHASAN}

Berdasarkan data yang diperoleh dari observasi pada 3 metode ekualisasi di lingkungan kolam dengan subjek yang sama, didapati bahwa dengan menggunakan metode Valsava rata-rata penyelam dapat menjangkau kedalaman terdalam hingga dasar kolam $(5 \mathrm{~m})$. Sedangkan dengan menggunakan metode menggerakkan rahang dan Toynbee penyelam rata-rata hanya mampu menjangkau kedalaman 3,4 $\pm 0,123$ meter dan $3,7 \pm 0,096$ meter. Capaian rata-rata kedalaman penyelaman menggunakan 3 metode ekualisasi dapat dilihat pada Tabel 1.

Tabel 1. Rata-rata capaian kedalaman menggunakan 3 metode ekualisasi

\begin{tabular}{lccc}
\hline & $\mathrm{N}$ & \multicolumn{2}{c}{ Mean } \\
\cline { 2 - 4 } & Statistic & Statistic & $\begin{array}{c}\text { Std. } \\
\text { Error }\end{array}$ \\
\hline Rahang & 40 & 3.40 & .12300 \\
Valsava & 40 & 5.00 & .00000 \\
Toynbee & 40 & 3.70 & .09608 \\
Valid N & 40 & & \\
(listwise) & & & \\
\hline
\end{tabular}

Sekilas tampak bahwa metode Valsava me-rupakan metode yang memiliki tingkat keber- 
hasilan tertinggi dalam mencapai kedalaman penyelaman, sedangkan metode menggerakkan rahang terlihat memiliki tingkat keberhasilan paling rendah dalam mencapai kedalaman penyelaman. Perbedaan tersebut divisualisasikan dalam Gambar 1.

Hasil uji normalitas Kolmogorov-Smirnov menunjukkan bahwa data tidak berdistribusi normal $(<0,05)$. Oleh karena itu uji beda yang dilakukan untuk mengetahui perbedaan rata-rata dari capaian ketiga metode ekualisasi tersebut adalah uji Kruskal-Wallis.

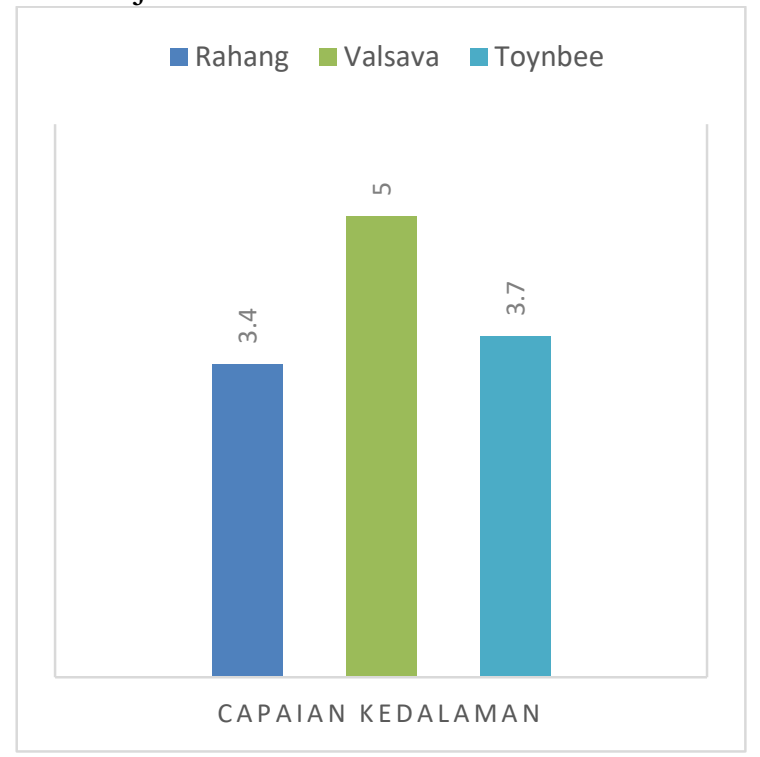

Gambar 1. Diagram Perbedaan rata-rata capaian kedalaman menggunakan 3 metode ekualisasi

Hasil Uji Kruskal-Wallis pada Tabel 2 menunjukkan bahwa $\mathrm{H}_{0}$ ditolak, sehingga berarti terdapat perbedaan antar ketiga metode ekualisasi. Hasil Post-Hoc Kruskal-Wallis yang terdapat pada Tabel 3 menunjukkan bahwa terdapat perbedaan yang signifikan antara capaian kedalaman menggunakan metode Valsava dengan capaian kedalaman menggunakan metode Toynbee $(\mathrm{p}<0,05)$ dan terdapat perbedaan yang signifikan pula antara capaian kedalaman menggunakan metode Valsava dengan capaian kedalaman menggunakan metode menggerakkan rahang $(\mathrm{p}<0,05)$. Namun tidak didapati adanya perbedaan yang signifikan antara data capaian kedalaman menggunakan metode menggerakkan rahang dengan capaian kedalaman menggunakan metode Toynbee $(\mathrm{p}>0,05)$.

Hasil penelitian menunjukkan bahwa tingkat keberhasilan tertinggi diperoleh dengan menggunakan metode ekualisasi Valsava. Hal ini dinyatakan dari kedalaman penyelaman yang berhasil dicapai menggunakan metode ekualisasi Valsava lebih dalam dari capaian menggunakan metode menggerakkan rahang dan Toynbee. Hal ini mungkin disebabkan karena metode ekualisasi Valsava dalam aplikasinya mampu mengalirkan udara dalam jumlah lebih besar dari kedua metode lainnya ke dalam ruang telinga tengah.

\section{Pendidikan Dasar Penyelaman}

Ekualisasi merupakan salah satu keterampilan dasar penyelaman yang wajib dikuasai oleh setiap penyelam, oleh karena itu sangat penting bagi instruktur untuk memastikan siswanya mampu melakukan ekualisasi dengan baik. Tidak jarang siswa mengalami kesulitan dalam melakukan ekualisasi dengan metode tertentu sehingga siswa perlu melatih suatu metode secara berulang-ulang. Tidak jarang pula seorang penyelam mampu melakukan suatu metode ekualisasi, namun gagal dalam melakukan ekualisasi menggunakan metode lain. Belum diketahui secara pasti penyebab perbedaan keberhasilan dan kegagalan ekualisasi pada masing-masing metode yang dilakukan oleh orang yang berbeda. Pada umumnya instruktur selam akan menginstruksikan kepada siswa atau kliennya untuk melakukan kombinasi antar ketiga metode ekualisasi ketika melakukan penyelaman. Mengombinasikan sedikitnya dua metode ekualisasi dipercaya memungkinkan ekualisasi dilakukan lebih cepat dibandingkan hanya menggunakan satu metode ekualisasi saja. Namun penelitian lebih lanjut diperlukan untuk membuktikan hal tersebut.

Tabel 2. Hasil Uji Kruskal-Wallis

\begin{tabular}{llll}
\hline \multicolumn{1}{c}{ Null Hypothesis } & \multicolumn{1}{c}{ Test } & Sig. & Decision \\
\hline $\begin{array}{l}\text { The distribution of A is the same across } \\
\text { categories of Samples }\end{array}$ & $\begin{array}{l}\text { Independent-Samples Kruskal- } \\
\text { Wallis Test }\end{array}$ & 0,000 & $\begin{array}{l}\text { Reject the null } \\
\text { hypothesis }\end{array}$ \\
\hline
\end{tabular}

Tabel 3. Post-Hoc Kruskal-Wallis

\begin{tabular}{lccccc}
\hline \multirow{2}{*}{ Sample } & Test & Std. & Std. Test & & \multirow{2}{*}{ Adj.Sig } \\
\cline { 2 - 5 } & Statistic & Error & Statistic & Sig & \\
\hline Ra - Toy & $-9,55$ & 7,361 & -1297 & 0,195 & 0,584 \\
Ra - Val & $-61,025$ & 7,361 & $-8,29$ & 0,000 & 0,000 \\
Toy - Val & 51,475 & 7,361 & 6,993 & 0,000 & 0,000 \\
\hline
\end{tabular}




\section{Penyelaman Profesional}

Selain sebagai olahraga dan rekreasi, selam juga sering dilakukan dalam rangka melakukan suatu pekerjaan profesional seperti perbaikan perangkat yang berada di bawah air, pencarian dan evakuasi korban tenggelam, serta aktivitas militer. Penyelaman profesional memerlukan tingkat keberhasilan ekualisasi yang tinggi demi menunjang kelancaran suatu pekerjaan. Kegagalan ekualisasi pada penyelaman profesional dapat mengganggu teknis pelaksanaan pekerjaan seperti memperpanjang durasi penyelaman yang berdampak pada bertambahnya penggunaan udara dalam silinder.

\section{Selam Bebas (Freediving)}

Selam bebas atau Freediving merupakan salah satu bentuk penyelaman yang sudah tidak asing di dunia selam dan sudah menjadi cabang olahraga selam tersendiri. Berbeda dengan penyelaman SCUBA, Freediving tidak menggunakan alat bantu pernafasan di dalam air (SCUBA). Pada olahraga freediving, seorang penyelam akan berusaha menahan nafas (apnea) saat menyelam dan berusaha mencapai kedalaman terdalam dan durasi terlama (Ostrowski et al., 2012). Umumnya Freediving hanya menggunakan masker, snorkel, fin panjang (long fin) dan pakaian selam (wet suit) yang lebih sederhana. Namun aktivitas menyelam bebas di bawah air tetap harus berhadapan dengan konsekuensi fisika yang sama, yaitu perubahan tekanan air yang menuntut penyelam bebas (freediver) untuk melakukan ekualisasi ketika menambah kedalaman penyelaman. Oleh karena freediver hanya melakukan satu tarikan nafas dan kemudian menahan nafas (apnea) selama durasi penyelaman, maka kegagalan melakukan ekualisasi pada freediving tidak jarang menyebabkan kepanikan diri penyelam dan penyelaman menjadi tidak efisien, terutama pada freediver pemula.

Dalam penyelaman bebas dikenal adanya suatu metode ekualisasi lain, selain dari metode Valsava, Toynbee dan menggerakkan rahang, yaitu dengan menekan langit-langit mulut menggunakan lidah. Belum diketahui apakah metode tersebut dapat diaplikasikan pada penyelaman SCUBA dan sebaliknya, juga belum jelas apakah metode tersebut lebih efektif dilakukan pada aktivitas freediving dibandingkan dengan metode Valsava, Toynbee dan menggerakkan rahang.

\section{SIMPULAN}

Hasil penelitian ini menunjukkan bahwa metode ekualisasi Valsava memiliki tingkat keberhasilan paling tinggi dibuktikan dengan capaian penyelaman yang paling dalam. Hal tersebut mungkin bisa disebabkan karena metode Valsava lebih dapat dikontrol dibandingkan dengan dua metode lainnya. Dengan demikian hasil penelitian ini dapat menjadi acuan bagi penyelam dalam aplikasi ekualisasi ketika melakukan penyelaman. Namun belum diketahui apakah hasil penelitian ini juga berlaku pada lingkungan air laut yang memiliki salinitas dan tekanan hidrostatis yang berbeda dengan air tawar. Penelitian lebih lanjut mungkin perlu dilakukan untuk membuktikan hal tersebut

\section{DAFTAR PUSTAKA}

Abshor, U. (2014, January 7). Pengaruh barotrauma auris terhadap gangguan pendengaran pada nelayan penyelam di Kecamatan Puger Kabupaten Jember. Universitas Jember. Retrieved from http://repository.unej.ac.id/handle/123456 789/13795

Bofe, J. H., Martinus, I., Natsir, N., \& Tawil, M. (2018). Implementasi kebijakan kesehatan penyelam di Kecamatan Balaesang Tanjung Kabupaten Donggala. Jurnal Kesehatan Masyarakat Indonesia, 13(1). Retrieved from https://jurnal.unimus.ac.id/index.php/jkmi /article/view/3441

Bove, A., \& Davis, J. (1990). Diving medicine (2nd ed.). Philadelphia: Saunders.

Brylske, A. (2006). The encyclopedia of recreational diving. United States: PADI.

Davenport, D. A. (1979). Boyle's law. Journal of Chemical Education, 56(5), 322. https://doi.org/10.1021/ed056p322.1

Dwipayana, I. M. P., Kusumawati, A. A. I. P., \& Prapti, N. K. G. (2017). Hubungan aktivitas menyelam dengan kapasitas vital paru pada penyelam di Desa Les, Kecamatan Tejakula, Kabupaten Buleleng. COPING (Community of Publishing in Nursing), 5(1), 44-55. Retrieved from https://ojs.unud.ac.id/index.php/coping/art icle/view/41210

Glazer, T. A., \& Telian, S. A. (2016). Otologic hazards related to scuba diving. Sports Health, $\quad 8(2), \quad$ 140-144. 
https://doi.org/10.1177/194173811663152 4

Green, S., Rothrock, S., \& Green, E. (1993). Tympanometric evaluation of middle ear barotrauma during recreational scuba diving. International Journal of Sports Medicine, 14(07), 411-415. https://doi.org/10.1055/s-2007-1021201

Gupta, S., \& Mittal, S. (2013). Yawning and its physiological significance. International Journal of Applied \& Basic Medical Research, 3(1), 11-15. https://doi.org/10.4103/2229516X.112230

Guyton, A. C., \& Hall, J. E. (2006). Textbook of medical physiology (11th ed.). Philadelphia: Elsevier Inc.

Hall, J. (2014). The risks of scuba diving: a focus on Decompression Illness. Hawai' $i$ Journal of Medicine \& Public Health: A Journal of Asia Pacific Medicine \& Public Health, 73(11 Suppl 2), 13-16.

Hart, A. J., White, S. A., Conboy, P. J., Bodiwala, G., \& Quinton, D. (1999). Open water scuba diving accidents at Leicester: five years' experience. Emergency Medicine Journal, 16(3), 198-200.

Lacey, J. P., \& Amedee, R. G. (2000). The otologic manifestations of barotrauma. The Journal of the Louisiana State Medical Society: Official Organ of the Louisiana State Medical Society, 152(3), 107-111.

McArdle, W. D., Katch, V. L., \& Katch, F. I.
(2009). Exercise hysiology: Nutrition, energy, and human performance (7th ed.). United States: Lippincott Williams \& Wilkins.

Neblett, L. M. (2000). Otolaryngology and sport scuba diving. Update and guidelines. The Annals of Otology, Rhinology \& Laryngology. Supplement, 152(3), 107111.

Ostrowski, A., Strzała, M., Stanula, A., Juszkiewicz, M., Pilch, W., \& Maszczyk, A. (2012). The role of training in the development of adaptive mechanisms in freedivers. Journal of Human Kinetics, 32, 197-210. https://doi.org/10.2478/v10078012-0036-2

Rithaudin, A. (2010). Aktivitas akuatik sebagai terapi psikis bagi anak. MEDIKORA, $V I(2)$. Retrieved from https://journal.uny.ac.id/index.php/medik ora/article/view/4690

Ruslam, R. D. C., Rumampuk, J. F., \& Danes, V. R. (2015). Analisis gangguan pendengaran pada penyelam di Danau Tondano Desa Watumea Kecamatan Eris Kabupaten Minahasa Provinsi Sulawesi Utara 2014. Jurnal E-Biomedik, 3(1).

Sastroasmoro, S., \& Ismael, S. (2011). Dasardasar metodologi penelitian klinis (4th ed.). Jakarta: Sagung Seto.

Sherwood, L. (2015). Fisiologi manusia: Dari sel ke sistem. (D. R. Herman Octavius Ong, Albertus Agung Mahode, Ed.) (8th ed.). Jakarta: EGC. 